\title{
Character First: Rethinking John McCain's 2008 Campaign Strategy
}

\author{
David B. Holian and Charles Prysby
}

Barack Obama's defeat of John McCain in 2008 was hardly surprising given the campaign's context, which was toxic for the Republican Party. Yet, in such perilous times, McCain enjoyed certain advantages, namely his reputation for strong leadership and his years of government experience that could have been profitably contrasted with Obama's relative youth and inexperience. Given these advantages, we speculate as to whether McCain could have pulled even with Obama in the popular vote by increasing his lead among persuadable voters on their perceptions of the candidates' character traits. Using ANES data on traits from 1988 to 2008, we conclude that, short of profound missteps by the Obama campaign, McCain would have had to accomplish more than simply shifting voter perceptions of character traits in a more favorable direction to win the election.

Circumstances were not kind to John McCain in 2008. The candidate and his campaign team undoubtedly understood that they faced a steep uphill climb to the White House. Most scholarly election forecasts, generated months before the November election, predicted a Democratic victory due to the poor economy and George W. Bush's anemic public approval. Six of the nine forecasts published in a $P S$ symposium predicted a victory for Barack Obama, giving the Democrat somewhere between a 72 percent and 92 percent chance of a popular vote victory. However, two other models saw the election as a toss up, and one predicted that McCain had an 83 percent chance to win (Campbell 2008, 681).

One factor that injected greater uncertainty into the election campaign, a factor unaccounted for by the forecast models, was Obama's status as the first African-American major-party nominee. The potential for race to skew public opinion polling and to influence voter decision making led scholars and journalists to consider previous state and local elections in order to gauge the potential impact of a candidate's race on election results. Some election observers have argued that minority candidates tend on election day to underperform their polling predictions, thus casting doubt on the size of Obama's consistent polling advantage during the summer and fall of 2008 . $^{1}$

DAVID B. HOLIAN is an associate professor of political science and at University of North Carolina at Greensboro. CHARLES PRYSBY is a professor of political science at University of North Carolina at Greensboro.

The American Review of Politics, Vol. 32, Winter, 2011-2012: 319-342

(c)2011 The American Review of Politics 
However, as the fall campaign unfolded, McCain's odds of victory lengthened as the nation's dismal economy became even more salient to voters, due partly to the collapse of the economy's financial sector just prior to the first presidential debate. Even before Lehman Brothers went under, the public considered the economy the most salient issue of the campaign and identified Obama as the candidate best able to handle it. ${ }^{2}$ In Petrocik's (1996) terms, trust in Obama ensured the Democrat's ownership of the economy; the fact that the issue was at the forefront of Americans' concerns ensured that Democratic ownership was consequential. Vavreck (2009) argues that these circumstances made Obama the obvious clarifying candidate in the campaign. Clarifying candidates make the economy the focus of their campaigns because they can either take credit for good economic times or credibly distance themselves from the policies most clearly associated with economic slumps (Vavreck 2009, 31-32). Indeed, over 60 percent of Obama's general election ads concerned the economy (Vavreck 2009, xxii).

With context and events aligned firmly against McCain, his only hope for victory was to move the campaign agenda toward the personal characteristics of the candidates. While Vavreck's typology pegs McCain as an insurgent candidate, this path was not easily available to the Republican. Insurgent candidates try to pivot the campaign agenda away from the economy toward another issue. Under the best of circumstances, such candidates have their "work cut out for them" (Vavreck 2009, 33). Crucially, the insurgent candidate's campaign redefining issue must not only be supported by a clear majority of the public, but also trap the clarifying candidate on the wrong side of mass opinion. Unfortunately for McCain, his ability to build an alternative issue-based insurgent campaign was quite limited. His party affiliation and military background gave him the potential to dominate national security discussion, but the economy's salience and war weariness combined to keep the Republican from gaining much traction on the issue. ${ }^{3}$ With the public focused on the economy, and Democratic ownership of the issue assured, McCain needed to make the election a referendum on personality.

Such a strategy was especially apt given McCain's seeming advantages on this score. First, because 2008 was an open-seat election and McCain was not in the Bush administration, character traits were likely to have a stronger effect on the vote relative to incumbent performance. Second, McCain could point to decades of experience in government and a reputation for strong leadership, gained in part based on a powerful biography and numerous examples of bucking his party's leadership. Such characteristics were a nice fit for perilous times and also had the potential to provide stark contrasts to Obama's relative youth and inexperience. In an age of terrorism, two ongoing wars, and economic dislocation, if a path to a McCain victory existed, 
it would likely lie in a clear and compelling distinction between the experienced military veteran and the untested and therefore risky newcomer.

McCain certainly attempted to present himself as superior to Obama in terms of character traits. His "Country First" campaign slogan evoked McCain's military background, personal sacrifice, and leadership credentials, as well as highlighting his integrity as someone who prioritizes the national interest above party politics. A number of McCain and RNC contrast and attack ads questioned Obama's lack of experience and labeled him as "not ready yet," "risky," and "untested." However, McCain failed to fully implement a "character-first" strategy in part because he undermined his strongest arguments for the presidency at various times during the campaign. The surprise selection of Sarah Palin - an untested and therefore risky newcomer - as his running mate sabotaged McCain's clear experience advantage. This decision, in combination with the ill-conceived "suspension" of his campaign to deal with the financial sector crisis, contributed to mainstream press coverage that portrayed McCain as reckless (Hershey 2010, 125). Moreover, the decision to sacrifice campaigning and debate preparation to travel to Washington and "play the statesman" provided an opening for Obama to counter that presidents rarely enjoyed the luxury of focusing on one issue or crisis at a time, which undermined McCain's leadership advantage (Ceaser et al. 2009, 147). ${ }^{5}$

If McCain had more vigorously and consistently emphasized character traits as the crucial question on which the election should turn, he may have made the election more competitive. This was suggested by an in-depth New York Times Magazine assessment of the McCain campaign, published shortly before the election (Draper 2008). The article detailed the many tactical shifts the McCain team had rather chaotically tested over the course of the campaign and suggested that highly placed McCain advisors thought that the advantages of their candidate's biography and personal strengths had been lost amidst the campaign's lurching from one theme to the next. Had the campaign maintained a consistent message focused on its candidate's courage, leadership abilities, and experience, McCain — at least according to his aides-would have won. In this study, we attempt to assess whether McCain had a reasonable chance of victory if he had been able to exploit more effectively his potential advantages on character traits.

Of course, to resonate, campaign claims must be credible. And here, Obama provided the McCain campaign with precious few examples of a weak and dangerously inexperienced candidate. While Palin's disastrous encounters with various media outlets helped make Tina Fey a household name and cemented Palin's reputation as ill prepared for high office, Obama gained recognition as calm and knowledgeable in the midst of the presidential campaign whirlwind that was made more intense by the worsening 
economy. Even if McCain had more effectively emphasized candidate character traits in his campaign, it may be that such an effort would still have been insufficient for victory without Obama missteps to exploit.

With such caveats in mind, we reconsider McCain's chances in 2008 in the following manner. We first examine how voters perceived the personal traits of the presidential candidates in 2008, comparing these perceptions to those in presidential elections since 1988. Next, we assess whether perceptions of Obama and McCain changed over the course of the campaign and whether trait perceptions influenced the 2008 vote. Finally, we try to answer the question: Could McCain have won? We believe that rethinking the 2008 campaign provides insight into the dynamics of voting behavior and electoral politics.

Our focus on the McCain campaign strategy is based on the assumption that Obama's strategy was unlikely to change even if McCain had focused more on character traits. While Obama deserves credit for his campaign's mastery of social networking, wildly successful fund-raising, and lack of (public) infighting, praise beyond the execution of Obama's general election campaign strategy is misplaced (Ceaser et al. 2009, 132). The dual approach of promoting change from a deeply unpopular status quo and linking McCain to Bush as often as possible was effective, but hardly innovative. ${ }^{6}$ The change theme is routinely available to the challenging party even when the incumbent enjoys strong public approval. For instance, John Kennedy made his New Frontier pledge in the waning days of the quite popular Eisenhower administration. ${ }^{7}$ Linking any and all Republican candidates to the unpopular Bush served the Democrats well in their 2006 takeover of the Congress, an election cycle that provided an obvious template for 2008 given that Bush became even less popular in his final two years. Moreover, Abramowitz's (2008) election forecast model suggests that change is the default strategy in a "Time-for-Change" election, which described 2008. Thus, while we note the problems inherent in reconsidering McCain's chances in the election, we argue that Obama's approach to the election was predictable, largely fixed, and unlikely to be altered more than marginally, regardless of variation in the McCain campaign's strategy.

\section{Voter Perceptions of Candidate Character Traits}

We define candidate character traits as falling into one of four categories: leadership, competence, integrity, and empathy. While there is not universal agreement that these four categories best encompass the trait dimensions by which Americans assess presidential candidates, many scholars have accepted them (see, e.g., Goren 2002; Kinder 1986; McCann 1990; Miller and Shanks 1996; Pierce 1993). ${ }^{9}$ Moreover, the American National 


\section{Table 1. Perceptions of Presidential Candidate Character Traits, 1988-2008}

\begin{tabular}{|c|c|c|c|c|c|c|c|c|}
\hline Year & Candidate & 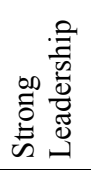 & 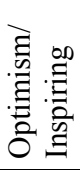 & 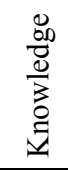 & 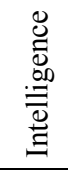 & 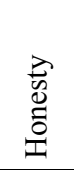 & 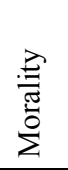 & 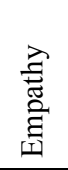 \\
\hline 2008 & $\begin{array}{l}\text { Obama } \\
\text { McCain }\end{array}$ & $\begin{array}{l}63.1 \\
66.1\end{array}$ & $\begin{array}{l}86.7 \\
63.8\end{array}$ & $\begin{array}{l}76.9 \\
78.9\end{array}$ & $\begin{array}{l}92.5 \\
81.2\end{array}$ & $\begin{array}{l}60.1 \\
63.7\end{array}$ & $\begin{array}{l}70.3 \\
70.0\end{array}$ & $\begin{array}{l}63.6 \\
44.9\end{array}$ \\
\hline 2004 & $\begin{array}{l}\text { Kerry } \\
\text { Bush }\end{array}$ & $\begin{array}{l}49.4 \\
64.3\end{array}$ & & $\begin{array}{l}79.8 \\
59.8\end{array}$ & $\begin{array}{l}85.1 \\
59.7\end{array}$ & $\begin{array}{l}73.5 \\
68.8\end{array}$ & $\begin{array}{l}66.8 \\
70.8\end{array}$ & $\begin{array}{l}57.4 \\
47.6\end{array}$ \\
\hline 2000 & $\begin{array}{l}\text { Gore } \\
\text { Bush }\end{array}$ & $\begin{array}{l}55.4 \\
65.8\end{array}$ & & $\begin{array}{l}83.1 \\
70.6\end{array}$ & $\begin{array}{l}83.8 \\
76.9\end{array}$ & $\begin{array}{l}71.3 \\
80.7\end{array}$ & $\begin{array}{l}74.7 \\
75.4\end{array}$ & $\begin{array}{l}58.7 \\
48.4\end{array}$ \\
\hline 1996 & $\begin{array}{l}\text { Clinton } \\
\text { Dole }\end{array}$ & $\begin{array}{l}56.7 \\
62.0\end{array}$ & $\begin{array}{l}51.3 \\
38.5\end{array}$ & $\begin{array}{l}84.4 \\
85.7\end{array}$ & $\begin{array}{l}89.1 \\
\text { n.a. }\end{array}$ & $\begin{array}{l}39.5 \\
70.9\end{array}$ & $\begin{array}{l}34.1 \\
80.7\end{array}$ & $\begin{array}{l}56.5 \\
43.7\end{array}$ \\
\hline 1992 & $\begin{array}{l}\text { Clinton } \\
\text { Bush }\end{array}$ & $\begin{array}{l}55.3 \\
54.9\end{array}$ & $\begin{array}{l}55.9 \\
37.7\end{array}$ & $\begin{array}{l}79.9 \\
83.0\end{array}$ & $\begin{array}{l}85.3 \\
83.0\end{array}$ & $\begin{array}{l}46.6 \\
59.7\end{array}$ & $\begin{array}{l}42.0 \\
79.8\end{array}$ & $\begin{array}{l}61.1 \\
35.6\end{array}$ \\
\hline 1988 & $\begin{array}{l}\text { Dukakis } \\
\text { Bush }\end{array}$ & $\begin{array}{l}51.2 \\
51.6\end{array}$ & $\begin{array}{l}43.7 \\
37.7\end{array}$ & $\begin{array}{l}79.8 \\
82.8\end{array}$ & $\begin{array}{l}86.8 \\
78.7\end{array}$ & $\begin{array}{l}72.0 \\
64.5\end{array}$ & $\begin{array}{l}73.9 \\
76.2\end{array}$ & $\begin{array}{l}61.6 \\
49.4\end{array}$ \\
\hline
\end{tabular}

Note: Entries for each candidate are the percentage of voters who said that the specified trait characterized the candidate extremely well or quite well, except for the data for honesty in 2000 and 2004. In those years, the entries are the percentage of voters who said that the candidate was not dishonest. In 2008, respondents were asked whether each candidate was optimistic, but the other years, they were asked whether each candidate was inspiring, except for 2000 and 2004, when no comparable question was asked. In 2008, the ANES introduced a revised five-category response set to half of its sample and maintained the usual four categories for the other half. To ensure comparability across years, the 2008 figures reflect only respondents in the half sample that received the four-category response set. See note 14 for further details.

Source: American National Election Study surveys, 1988-2008. Only voters are included in the analysis.

Election Study has, over time, included questions concerning individual candidate traits that serve as measures of these four underlying categories. Table 1 displays these perceptions from 1988 through 2008 for ANES respondents who reported voting. Cell entries represent the percentage of respondents in each year who answered that the trait indicated in each column described a candidate either extremely well or quite well. ${ }^{10}$

Voter perceptions of trait strengths and weaknesses are based not only on candidates' personalities, experiences, and campaign appeals, but the party label as well. Hayes (2005) argues that voters tend to consider Republican candidates to be stronger leaders, while Democratic candidates tend to be identified with greater empathy. The concept of trait ownership flows 
from issue ownership, which suggests that Republicans are advantaged when the campaign or governing agenda focus on issues related to national security, an issue domain that emphasizes strong leadership, while Democrats gain when the spotlight turns to Social Security or education, issues that highlight empathy (Petrocik 1996; Holian 2006).

As Table 1 demonstrates, Republican candidates bested Democrats on strong leadership, with the single exception of 1992. On the other hand, Republican candidates George H.W. Bush and Bob Dole faired poorly on another dimension of leadership, the ability to inspire people. All Democratic candidates surpassed Republicans on empathy by substantial margins, a trait measured by assessments of whether a candidate "really cares" about people like the respondent. Table 1 exhibits no other consistent party effects. George W. Bush trailed his Democratic opponents on the two competence measures, knowledge and intelligence, but other Republican candidates were competitive on these attributes. Likewise, Bill Clinton faced substantial deficits on the two integrity items, honesty and morality, but no other Democrat faired so poorly. ${ }^{11}$ Another pattern emerges from Table 1: while victorious candidates are never perceived more positively on every trait, winners minimize their opponent's inherent, party-based trait advantage. In other words, the Republicans who trailed by the widest margins on empathy lost. Democratic candidates faced a similar fate on the strong leadership item, with the exception of 1988, a year in which neither presidential candidate impressed the electorate with their leadership claims.

This brings us to 2008. Coming into the campaign, McCain's strengths on leadership and knowledge must have seemed especially fertile ground for contrasts with Obama. The young Democrat was relatively new to national politics; during the Democratic primary, he was attacked by Hillary Clinton on the basis of his inexperience and readiness to lead. ${ }^{12}$ However, ANES respondents assessed McCain only slightly more favorably than Obama on leadership. With the exception of the elder Bush's atypically low scores in 1988 and 1992, McCain's leadership rating was in line with other Republican candidates, whose scores ranged from 62.0 percent to 66.1 percent. Obama's leadership rating of 63.1 percent, on the other hand, was at least 6 points better than that of any other Democrat in the years displayed in the table.

McCain's advantage on voter perceptions of the candidates' knowledge was even narrower. While Obama, unsurprisingly, received the lowest knowledge rating among all candidates since 1988, other than the competence-impaired George W. Bush, McCain received the second lowest. Both of his long-serving Senate colleagues, Kerry in 2004 and Dole in 1996, outscored McCain, Dole by nearly 7 percentage points. Thus, McCain gained little advantage on the two character attributes that comprised his campaign's 
best hope of portraying his opponent as a risky choice for uncertain times. While McCain failed to press his inherent advantages, Obama enjoyed the largest empathy lead of any Democrat other than Clinton in 1992.

As to the other traits displayed in Table 1, Obama enjoyed a doubledigit advantage on intelligence. This gap had less to do with perceptions of McCain's intelligence, which was in line with other candidates, than with the extraordinarily positive perceptions of Obama's. The Democratic candidate's rating of 92.5 percent is the only trait score higher than 90 percent on any item. This finding suggests that one of the McCain campaign's most memorable tactics, its pre-convention ad painting Obama as a vacuous celebrity akin to Britney Spears or Paris Hilton, was more media sensation than persuasive argument against the Democrat. ${ }^{13}$ Neither candidate held an appreciable advantage on the integrity measures, honesty and morality. The candidates' scores on these traits were similar to each other and in line with other candidates in the table.

Finally, we turn to optimism. The 2008 survey represents the first time the ANES asked how well the phrase "he is optimistic" described the candidates. We have included optimism in the same column in Table 1 as the question about being inspiring because our expectation is that being optimistic and being inspiring are similar characteristics that form part of a larger leadership dimension. Moreover, scholarly and popular accounts of past presidents often focus on an ability to be a beacon of optimism and inspiration in troubled times. Greenstein (2009, 16-17) describes Franklin Roosevelt in this way; Ronald Reagan has been depicted in a similar way. While we cannot compare 2008 perceptions of optimism to those in other years, Table 1 shows that Obama maintained about a 23-point advantage on this characteristic. If optimism, like being inspiring, is part of leadership, then Obama's ability to communicate a hopeful vision of the future more than made up for McCain's slight advantage on perceptions of strong leadership.

Perceptions of all these traits are related to one another. Voters who saw Obama as superior to McCain on one trait were likely to see him as superior on the others as well. Much of this results from the simple fact that trait perceptions are influenced by party identification and ideology, as we shall discuss later. Nevertheless, voters make distinctions between different traits. They assign higher scores to a candidate on some traits than on others, as Table 1 shows. Moreover, perceptions of individual traits do not necessarily change in the same direction over time. As discussed below, Obama gained over the course of the election when it came to perceptions of leadership and knowledge, yet lost ground on perceptions of integrity. This indicates that candidate behavior and campaign events influence perceptions of specific traits. 


\section{Analyzing the Influence of Trait Perceptions in the Election}

As we have seen, McCain was unable to gain a clear advantage over Obama on character traits. Nevertheless, we can ask whether he had any chance of success. That is, if he had run a better campaign, is it conceivable that he could have gained a sufficient advantage on character traits to have won? Asking this question presupposes that voter trait perceptions can change during the campaign, particularly in response to events and/or campaign communication efforts, and that these trait perceptions influence the vote. If perceptions of character traits are set prior to the general election campaign, with minimal subsequent alteration in these perceptions, then there is little reason to pursue this analysis. Similarly, if perceptions of candidate character traits have little influence on the vote, then there also is little reason to consider whether McCain might have been able to win had he secured a greater advantage on trait perceptions.

We first consider whether candidate trait perceptions can change over the course of a campaign. The nature of the 2008 election, which matched a relative newcomer against someone who had been in public life for decades, suggests that perceptions of Obama would be more subject to change. To test whether perceptions of the candidates changed during the campaign, we regressed voter assessments of each candidate trait listed in Table 1 on party identification and the number of days left in the campaign at the time of the ANES interview, which took place up to 63 days prior to the election. Our results (data not shown) show that perceptions of Obama changed significantly. White and other non-black voters became more likely to associate the terms "strong leader" and "knowledgeable" with the Democrat as the campaign progressed. Conversely, voters interviewed later in the campaign came to see Obama as less moral, honest, and caring. Perceptions of McCain's character traits changed less, as we would expect, but voters did see him as less honest and moral as election day approached. The overall effects of the passage of time were limited to one-third of a point on each five-point trait perception scale, but certain subgroups, such as independents, were more strongly affected. While our data are admittedly not ideal for testing overtime effects, the results are suggestive. Voter perceptions of the candidates changed during the campaign, and they did so to the McCain campaign's detriment on two traits that should have been distinct advantages: leadership and knowledge.

We also need to know what effect voter perceptions of candidate character traits had on the vote. To answer this question, we formed an index of trait perceptions, which is the respondent's mean score on the seven trait perception items for McCain minus the mean score for the seven trait perception items for Obama. Each trait item is scored from +2 (extremely well) 
to -2 (not at all). ${ }^{14}$ If a respondent gave McCain the highest possible score and Obama the lowest possible score on each of the trait items, that respondent would have a trait index score of 4.0. An index score of -4.0 would indicate exactly the opposite pattern of responses, and an index score of zero would mean that the respondent had an equally favorable overall evaluation of each candidate's traits. We then used logistic regression to determine how strongly trait perceptions were related to the vote.

In addition to the trait index, we included a number of other variables in the analysis for control purposes: (a) party identification and ideology were included as fairly stable political orientations that affect many attitudes ${ }^{15}$ (b) a measure of the respondent's evaluation of national economic conditions was constructed from three questions about the condition of the economy and Bush's economic performance; ${ }^{16}$ (c) an index of attitudes toward national security policy was constructed from several questions about the wars in Iraq and Afghanistan and the general war on terrorism; ${ }^{17}$ (d) a measure of attitudes on domestic social welfare issues was created from a number of variables; ${ }^{18}$ (e) an index of attitudes on moral issues was created from questions about abortion and gay rights; ${ }^{19}$ and (e) given the particular significance of race in this presidential election, an index of attitudes toward blacks was included in the analysis. ${ }^{20}$

The results of our logistic regression analysis are in Table 2. Model 1 predicts the presidential vote using only party identification and ideology; these variables alone allow for a fairly good prediction of the vote. Next, we added in the various attitudinal indices (model 2), which improves our predictive ability. Also, the coefficients for party identification and ideology diminish, indicating that some of the effect on the vote of these two variables occurs indirectly through effects on various issue and performance attitudes. Finally, we added in the trait index (model 3 ). Our ability to predict the vote is increased even more, indicating that trait perceptions have a separate and independent effect on the vote. The coefficient for the trait index is quite strong, and the Wald score is higher than for any other variable save party identification. Again, we can see that the coefficients for a number of the other variables decrease from model 2 to model 3, suggesting that some of the effects of these variables occur through effects on the perceptions of candidate character traits, a point we discuss later in this article.

The results of a logistic regression are difficult to interpret if the regression coefficients are not translated into predicted probabilities. Figure 1 shows the predicted probability of voting for McCain for average Democrats, Republicans, and independents for different trait index scores. ${ }^{21} \mathrm{Al}-$ though the trait index runs from +4.0 to -4.0 , we display predicted probabilities only for scores between +1.0 and -1.0 . About one-half of the voters fell in this range, and more extreme scores are found almost entirely in the 
Table 2. Logistic Regression of Presidential Vote, 2008

\begin{tabular}{|c|c|c|c|}
\hline Independent Variable & Model 1 & Model 2 & Model 3 \\
\hline $\begin{array}{l}\text { Party } \\
\text { identification }\end{array}$ & $\begin{array}{c}.865 * * * \\
(.054)\end{array}$ & $\begin{array}{c}.628 * * * \\
(.063)\end{array}$ & $\begin{array}{c}.595 * * * \\
(.076)\end{array}$ \\
\hline Ideology & $\begin{array}{c}.646^{* * *} \\
(.084)\end{array}$ & $\begin{array}{l}.384 * * * \\
(.106)\end{array}$ & $\begin{array}{l}.197 \\
(.121)\end{array}$ \\
\hline $\begin{array}{l}\text { Retrospective evaluations } \\
\text { of the economy }\end{array}$ & & $\begin{array}{l}.458 * * \\
(.181)\end{array}$ & $\begin{array}{l}.023 \\
(.202)\end{array}$ \\
\hline $\begin{array}{l}\text { National security } \\
\text { issues index }\end{array}$ & & $\begin{array}{l}1.219 * * * \\
(.214)\end{array}$ & $\begin{array}{l}.692 * * \\
(.248)\end{array}$ \\
\hline $\begin{array}{l}\text { Social welfare } \\
\text { issues index }\end{array}$ & & $\begin{array}{l}.117 \\
(.121)\end{array}$ & $\begin{array}{l}.117 \\
(.144)\end{array}$ \\
\hline $\begin{array}{l}\text { Attitudes toward } \\
\text { blacks index }\end{array}$ & & $\begin{array}{l}1.529 * * * \\
(.260)\end{array}$ & $\begin{array}{l}.856^{* *} \\
(.292)\end{array}$ \\
\hline $\begin{array}{l}\text { Moral issues } \\
\text { index }\end{array}$ & & $\begin{array}{l}.670 * * * \\
(.147)\end{array}$ & $\begin{array}{c}.745 * * * \\
(.166)\end{array}$ \\
\hline \multirow[t]{2}{*}{$\begin{array}{l}\text { Candidate trait } \\
\text { index }\end{array}$} & & & $\begin{array}{l}1.552 * * * \\
(.158)\end{array}$ \\
\hline & $\begin{array}{c}-2 \mathrm{LL}=813.89 \\
\text { Nagel. } \mathrm{R}^{2}=.70 \\
\% \text { cases correctly } \\
\text { predicted }=88.4\end{array}$ & $\begin{array}{c}-2 \mathrm{LL}=655.03 \\
\text { Nagel. } \mathrm{R}^{2}=.76 \\
\% \text { cases correctly } \\
\text { predicted }=89.5\end{array}$ & $\begin{array}{c}-2 \mathrm{LL}=500.12 \\
\text { Nagel. } \mathrm{R}^{2}=.83 \\
\% \text { cases correctly } \\
\text { predicted }=92.8\end{array}$ \\
\hline
\end{tabular}

Note: Only major party voters are included in the analysis. Black voters are excluded from the analysis. Entries are logistic regression coefficients. Standard errors are in parentheses. The dependent variable is the presidential vote. See the text for details on the independent variables. Positive coefficients indicate that the likelihood of voting for McCain is increased by having a stronger Republican identification, a more conservative ideological orientation, stronger approval of Bush's handling of the economy, more conservative orientations on the four issue indices, and more positive views of McCain's traits relative to Obama's.

Source: 2008 American National Election Study.

expected partisan group (e.g., scores above 1.0 occur among Republicans), so there is little point in examining predicted probabilities outside of this range. The biggest effect of trait perceptions on the vote occurs among independents. Democrats and Republicans are less influenced by their trait perceptions, but there still are clear effects. For example, the average white Democrat with a neutral attitude on candidate character traits had a .12 
Figure 1. Predicted Probabilities of a McCain Vote among Major Party Presidential Voters by Candidate Trait Index Score (excluding Black Voters)

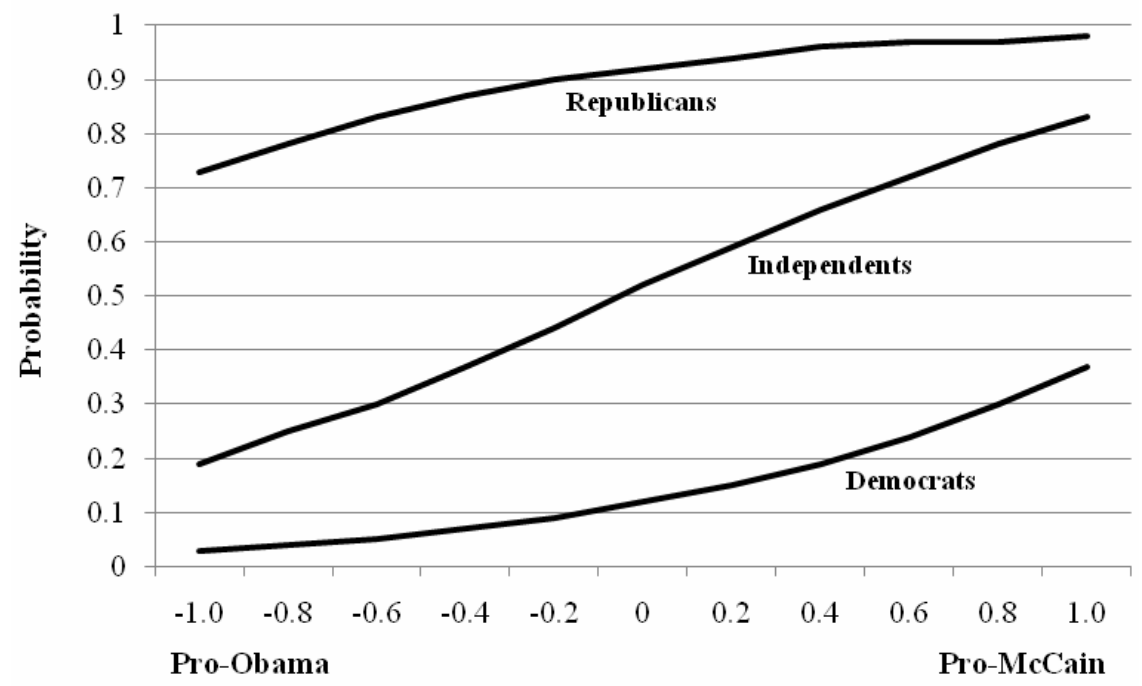

Candidate Trait Index Score

Note: The lines represent the probabilities of voting for McCain among white and other non-black major party presidential voters in 2008 for selected trait index scores. Although the trait index ranges from +4.0 to -4.0 , only scores between +1.0 and -1.0 are displayed, as the majority of voters were in this range. The probabilities were predicted using model 3 in Table 2. See the text for the definition of average Democrats, average independents, and average Republicans.

predicted probability of voting for McCain, whereas one with a trait index score of 0.40 (moderately favorable to McCain) had almost a 20 percent likelihood of defecting.

The analysis above examines the overall influence of trait perceptions on the vote. We also may be interested in determining whether some traits have more effect than others. To do this, we reran the analysis reported in Table 2, substituting four specific trait measures for the overall index, each of which is measured in exactly the same way as the trait index $(+4.0$ to -4.0). We selected these four specific trait measures because they best represent the four trait dimensions most frequently identified in the literature: leadership, competence, integrity, and empathy. To save space, we only report the coefficients for the trait items in Table 3. Leadership appears to have the biggest impact on the vote, followed by integrity and empathy. Competence (knowledge) appears to have little effect. However, we should be cautious in concluding that this is the case. It may be that perceptions of 
competence affect perceptions of leadership, so the effect on the vote is indirect rather than direct. The two trait measures are highly correlated $(\mathrm{r}=.71)$, and there are good theoretical reasons to think that these traits are tightly linked. What we can conclude from Table 3 is that McCain clearly would have benefitted if he had been able to secure a greater advantage on leadership, but he may or may not have been helped by a bigger advantage on knowledge or experience.

Table 3. Logistic Regression of Presidential Vote, 2008

\begin{tabular}{|c|c|}
\hline Character Trait & Coefficients \\
\hline Strong leader & $\begin{array}{c}.456^{* * * *} \\
(.102)\end{array}$ \\
\hline Knowledgeable & $\begin{array}{l}.093 \\
(.113)\end{array}$ \\
\hline Honest & $\begin{array}{l}.367 * * \\
(.122)\end{array}$ \\
\hline \multirow[t]{2}{*}{ Cares about people } & $\begin{array}{l}.267 * \\
(.105)\end{array}$ \\
\hline & $\begin{array}{c}-2 \mathrm{LL}=476.33 \\
\text { Nagel. } \mathrm{R}^{2}=.83 \\
\% \text { cases correctly } \\
\text { predicted }=92.3\end{array}$ \\
\hline \multicolumn{2}{|c|}{$* * * \mathrm{p}<.001, * * \mathrm{p}<.01, * \mathrm{p}<.05$ (two-tailed tests). } \\
\hline \multicolumn{2}{|c|}{$\begin{array}{l}\text { Note: Only major party voters are included in the analysis. Black voters are excluded from the analy- } \\
\text { sis. Entries are logistic regression coefficients. Standard errors are in parentheses. The dependent } \\
\text { variable is the presidential vote. See the text for details on the independent variables. Positive coeffi- } \\
\text { cients indicate that the likelihood of voting for McCain is increased by having a stronger Republican } \\
\text { identification, a more conservative ideological orientation, stronger approval of Bush's handling of } \\
\text { the economy, more conservative orientations on the four issue indices, and more positive views of } \\
\text { McCain's traits relative to Obama's. }\end{array}$} \\
\hline
\end{tabular}

Source: 2008 American National Election Study.

\section{Calculating the Possibility of a McCain Victory}

These results indicate that McCain would have won more votes if he had been able to do better on trait perceptions. But how much better did he need to do to capture a majority of the two-party vote? To answer this question, we focus on what percentage McCain needed to win among white and other non-black voters. Among the ANES respondents, McCain won slightly 
less than one percent of the vote of black major-party voters, and it seems unlikely that he could have improved on this figure. Among all other ANES respondents, McCain won 51.6 percent of the vote of major-party voters; when combined with his few votes from black voters, this gave McCain 45.2 percent of the vote of all major-party voters in the ANES survey. In order to have won 50 percent of all major-party voters in the survey, McCain would have needed 57.0 percent of the vote from white and other non-black major-party voters. However, the ANES survey sample had a small proObama bias. McCain won 45.2 percent of the two-party vote in the survey, but according to the Federal Election Commission's official results, he won 46.3 percent of the national two-party vote. If we wish to correct for this 1.1 point bias in the survey, then we can hypothesize that if McCain had won 48.9 percent of the major-party vote in the ANES survey, he would have won 50.0 percent of the national two-party vote. To have captured 48.9 percent of the two-party vote in the survey would have required winning 55.8 percent of the vote from white and other non-black major-party voters (assuming no change in support from black voters). Thus, we estimate that if McCain had won an additional 4.2 percent of the vote from white and other non-black voters in the survey, he would have been even with Obama in the national popular vote. Table 4 summarizes these calculations.

To determine how much better McCain would have needed to do on trait perceptions to win that additional 4.2 percent, we focus on potentially persuadable voters, those that might have been induced to vote for him. We consider potentially persuadable voters to be non-black respondents who had a predicted probability of voting for McCain that was less than but still reasonably close to .50 in our logistic regression analysis. Not only did these voters have attitudes that made them only weakly committed to Obama, they also were the voters who were more likely to have their trait perceptions changed by campaign behavior on the part of the candidates. Our analysis identified 52.9 percent of non-black major-party voters as predicted McCain voters (i.e., their predicted probability of voting for McCain was above .50), which is slightly greater than the 51.6 percent that he actually received from this group. Another 4.2 percent had a predicted probability of voting for McCain that was between .29 and .50. If this group of persuadable voters had their predicted probability of voting for McCain increased to above .50 , then 57.1 percent of white and other non-black voters would have been predicted McCain voters. Based on the fact that MCain's predicted vote was 1.3 points more than what he actually received from this group of ANES respondents, this 57.1 percent predicted vote should have translated into 55.8 percent of the vote from non-black major-party voters in the ANES survey, the target figure that we calculated as necessary for McCain to win 50 percent of the actual two-party vote (see Table 4 for a summary of these calculations). 


\section{Table 4. Received and Needed McCain Share of Vote Among Various Groups}

\begin{tabular}{|c|c|c|c|}
\hline & Received & Needed & Difference \\
\hline $\begin{array}{l}\text { McCain \% of actual two-party vote } \\
\text { (from FEC official election results) }\end{array}$ & 46.3 & 50.0 & 3.7 \\
\hline $\begin{array}{l}\text { McCain \% of two-party vote among } \\
\text { ANES respondents }\end{array}$ & 45.2 & 48.9 & 3.7 \\
\hline $\begin{array}{l}\text { McCain \% of two-party vote among } \\
\text { non-black ANES respondents }\end{array}$ & 51.6 & 55.8 & 4.2 \\
\hline $\begin{array}{l}\text { McCain \% of predicted two-party vote } \\
\text { among non-black ANES respondents }\end{array}$ & 52.9 & 57.1 & 4.2 \\
\hline \multicolumn{4}{|c|}{$\begin{array}{l}\text { Note: Figures in the "Needed" category represent what McCain needed to receive in order to achieve } \\
50 \text { percent of the actual two-party vote. Figures in the "Difference" category represent the difference } \\
\text { between what McCain needed and what he received. See the text for further explanation of these } \\
\text { figures. }\end{array}$} \\
\hline
\end{tabular}

Based on our logistic regression analysis, a respondent with a predicted probability of voting for McCain equal to .29 would require an increase of about .57 in his or her trait index score to move to a predicted probability of .50 of voting for McCain, assuming no change in any other attitudes. ${ }^{22}$ For respondents with a predicted probability of voting for McCain that was closer to .50 , a somewhat smaller increase in the trait index score would be required to make them into predicted McCain voters. In the abstract, an increase of .57 in the trait index score is not that great. For example, a change from rating McCain as unfavorable (i.e., the trait fits "not very well") to favorable (the trait fits "very well") on just one of the seven traits, combined with a change of rating Obama from favorable to unfavorable on just one trait would be sufficient. Of course, many other combinations of change also would yield an increase of .57 in the trait index score. Furthermore, persuadable voters should be more likely to be influenced by the campaign behavior of the candidates. Strong partisans on both sides are probably unlikely to change their views of the candidates very much, but McCain did not need to target these voters. From this perspective, it does not seem farfetched to think that a better campaign performance from McCain, combined with a worse performance from Obama, could have produced changes in trait perceptions of this magnitude among persuadable voters.

However, if we compare trait perceptions in 2008 with those in previous elections, a different perspective emerges, one that makes the possibility of McCain succeeding seem much less likely. To illustrate McCain's 
challenge, we compare trait perceptions in 2008 with those for the previous five presidential elections. Table 5 has mean scores on the six trait items that were asked in all of the years for white and other non-black independent voters. ${ }^{23}$ White (and other non-black) independents were a key component of persuadable voters in 2008 , and they are a clearly identifiable and comparable group across the years, so examining how well McCain did among these voters, compared to the performance of other recent candidates, will illustrate how difficult it would have been for McCain to have done substantially better among persuadable voters. In reading this table, keep in mind that McCain needed to increase the score for each trait item by an average of $.57 \mathrm{in}$ order to achieve the share of the predicted vote that we calculated as necessary for him to obtain a popular vote plurality. One also can look at Table 1, which has perceptions for all voters, not just white independents, for a broader perspective.

McCain hoped to secure a big advantage over Obama on leadership and competence, based on his lengthy government service and Obama's inexperience. In fact, his advantage over Obama on leadership was the highest received by any candidate among white (and other non-black) independents over the past six elections. His advantage on knowledge, which we regard as

\section{Table 5. Mean Scores for Individual Trait Items among White Independent Voters, 1988-2008}

\begin{tabular}{lrrrrrr}
\hline Character Trait & 1988 & 1992 & 1996 & 2000 & 2004 & 2008 \\
\hline Leadership & .09 & -.05 & .44 & .54 & .29 & .56 \\
Knowledge & .18 & .09 & .20 & -.25 & -.83 & .60 \\
Intelligence & -.18 & .04 & n.a. & -.03 & -.94 & -.16 \\
Honesty & -.19 & .44 & 1.27 & .37 & -.32 & .58 \\
Morality & .17 & 1.14 & 1.68 & .23 & .14 & .18 \\
Empathy & -.27 & -.08 & -.11 & .03 & -.48 & -.14 \\
$\begin{array}{l}\text { Mean score for } \\
\text { all six traits }\end{array}$ & -.33 & .26 & .70 & .15 & -.36 & .27
\end{tabular}

Note: Entries are mean scores for the individual trait items. A positive score indicates a higher score for the Republican candidate than for the Democratic candidate on the specified trait. A negative score indicates a higher score for the Democratic candidate than for the Republican candidate. The scores are for all non-black, independent, voters.

Source: Source: American National Election Study surveys, 1988-2008. 
a surrogate for experience, was second only to the advantage that Kerry held over Bush in 2004. Arguably, a more effective campaign strategy and effort by McCain, one that better exploited the vast differences between the candidates in government service, could have yielded a greater advantage on leadership and experience. However, it is highly unlikely that he could have improved his advantage on leadership and knowledge by .57; such an increase would have produced net scores of between 1.1 and 1.2 on these trait items, scores that would have been far larger than those received from persuadable voters by any candidate in the previous five elections. Only a truly inept performance by Obama during the debates, media interviews, and other campaign events - a performance perhaps on the order of Sarah Palin's - would have produced trait scores of that magnitude.

McCain also did well on honesty among white independents. His advantage on this trait item also was second best during this time span, eclipsed only by Dole's enormous advantage in 1996, which stemmed from the unusually poor perception of Clinton's integrity. On the other hand, McCain's advantage on morality was only average for Republican candidates, outside of the two years that Clinton was a candidate. Overall, McCain had a significant but not overwhelming advantage on integrity among white independents. If he had been able to achieve the advantage that Dole had on integrity in 1996, or even the advantage that Bush had in 1992, this would have contributed greatly to the overall advantage on character traits that he needed for victory. However, the potential for an enormous advantage on integrity may not have existed, as Obama lacked the integrity liabilities that Clinton possessed. While Republicans and the media raised questions about Obama's truthfulness regarding his associations with William Ayers, Tony Rezko, and the Reverend Jeremiah Wright, these probably were insufficiently important to produce highly negative views of Obama's honesty or morality. McCain might have been able to capture a somewhat greater advantage on integrity, but it is doubtful that he could have obtained anywhere near the advantage that Republican candidates had in 1992 or 1996.

Empathy is a trait dimension that Democrats almost always do better on, as we discussed earlier. For McCain to have secured a sizable advantage on empathy would have required him to accomplish what no Republican had been able to achieve in the previous five elections. The best that a Republican candidate did on this trait among white independents was the slight advantage that Bush obtained in 2000. There is little reason to think that an improved campaign effort or a better campaign strategy by McCain could have done much better than Bush did in 2000 on empathy, which was far less than the increase that McCain needed in trait perceptions. 
In sum, the analysis of the data in Table 5 indicates that McCain had little chance of overtaking Obama in the popular vote by presenting himself as superior on character traits. There are two reasons for this. First, while the entire electorate did not view McCain as superior overall to Obama on character traits (as Table 1 shows), white independents, who constituted most of the persuadable voters, did evaluate McCain quite favorably, especially on leadership, experience, and integrity. Given his already highly favorable marks, substantially greater performance was unlikely, given what previous candidates had been able to achieve. Second, the pool of persuadable voters was small. On the basis of party identification, ideology, and retrospective evaluations of President Bush's performance, a substantial number of voters were strongly committed to vote for Obama; others were solidly for McCain. As measured by the predicted probability of voting for McCain, relatively few voters were close to 50/50, which meant that McCain had to win over voters who otherwise were clearly leaning toward Obama, and to do so required him to outscore Obama on trait perceptions by a large amount.

More insight into the difficulties facing McCain is provided by an analysis of the factors that affect trait perceptions. Table 6 presents the results of a regression analysis of trait index scores for white and other nonblack voters. Perceptions of candidate character traits are influenced by party identification and ideology, as we would expect. They also are affected by retrospective evaluations of the economy, even in a year when the incumbent president was not running. The very negative views that voters had of the economy increased the probability that voters would assess Obama's character traits more favorably and McCain's less favorably. Also, trait perceptions were strongly influenced by attitudes on national security issues, which included evaluations of government performance regarding the wars in Iraq and Afghanistan. Dissatisfaction with the Bush administration in these areas also contributed to Obama's advantage on character traits. While the behavior of the candidates and the nature of their campaigns influence voter perceptions of traits, other factors also shape these perceptions. Significantly, the political context matters. The ability of the McCain campaign to convince voters that McCain was clearly superior to Obama across a range of character traits was greatly hampered by the widespread dissatisfaction with the Bush administration, a reality that the Obama campaign consistently emphasized and that the McCain campaign was largely powerless to alter. McCain desperately needed to win the battle over which candidate had the personal characteristics best suited for the White House crucible; however, from the McCain campaign's perspective, this battle was fought on highly unfavorable terrain. 
Table 6. Regression Analysis of Candidate Trait Index, 2008

\begin{tabular}{|c|c|c|}
\hline Independent Variable & All voters & Independent voters \\
\hline Party identification & $\begin{array}{l}.188 * * * \\
(.020) \\
{[.271]}\end{array}$ & $\begin{array}{l}.350 * * * \\
(.066) \\
{[.252]}\end{array}$ \\
\hline Ideology & $\begin{array}{l}.117 * * * \\
(.028) \\
{[.113]}\end{array}$ & $\begin{array}{c}.068 \\
(.049) \\
{[.070]}\end{array}$ \\
\hline Retrospective evaluations of the economy & $\begin{array}{l}.251 * * * \\
(.047) \\
{[.124]}\end{array}$ & $\begin{array}{l}.270 * * * \\
(.083) \\
{[.156]}\end{array}$ \\
\hline National security issues index & $\begin{array}{l}.563 * * * \\
(.064) \\
{[.242]}\end{array}$ & $\begin{array}{l}.578 * * * \\
(.110) \\
{[.279]}\end{array}$ \\
\hline Social welfare issues index & $\begin{array}{l}.098 * * \\
(.033) \\
{[.012]}\end{array}$ & $\begin{array}{c}.076 \\
(.056) \\
{[.056]}\end{array}$ \\
\hline Attitudes toward blacks index & $\begin{array}{l}.568 * * * \\
(.065) \\
{[.180]}\end{array}$ & $\begin{array}{l}.421 * * * \\
(.113) \\
{[.157]}\end{array}$ \\
\hline Moral issues index & $\begin{array}{l}.063 \\
(.040) \\
{[.035]}\end{array}$ & $\begin{array}{c}.056 \\
(.070) \\
{[.036]}\end{array}$ \\
\hline $\begin{array}{l}\text { Adjusted } \mathrm{R}^{2} \\
(\mathrm{~N})\end{array}$ & & \\
\hline \multicolumn{3}{|l|}{$* * * \mathrm{p}<.001, * * \mathrm{p}<.01, * \mathrm{p}<.05$ (two-tailed tests) } \\
\hline \multicolumn{3}{|c|}{$\begin{array}{l}\text { Note: Only major party voters are included in the analysis. Black voters are excluded from the } \\
\text { analysis. Independent voters include leaners. Entries are unstandardized OLS regression coeffi- } \\
\text { cients. Standard errors are in parentheses. Standardized regression coefficients are in brackets. The } \\
\text { dependent variable is the candidate trait index. See the text for details on the independent variables } \\
\text { Positive coefficients indicate that a trait index score that is more favorable to McCain is related to } \\
\text { having a stronger Republican identification, a more conservative ideological orientation, stronger } \\
\text { approval of Bush's handling of the economy, and more conservative orientations on the four issue } \\
\text { indices. }\end{array}$} \\
\hline
\end{tabular}

Source: 2008 American National Election Study. 


\section{Conclusion}

Perceptions of the character traits of the presidential candidates mattered in 2008. Those with more favorable views of one candidate, relative to the other, were more likely to vote for that candidate, even with other relevant attitudes taken into account. Obama did better overall than did McCain on trait perceptions among voters. He was about even with McCain on leadership, integrity, and knowledge, all areas where McCain potentially could have gained a significant advantage. On other factors, most notably empathy and optimism, voters perceived Obama far more positively than McCain. Nevertheless, McCain did well among white independents, a key group of swing voters. This subset of voters saw McCain as substantially superior to Obama on leadership, experience, and integrity. However, for McCain to have won a majority of the popular vote, he would have needed an enormous advantage on trait perceptions among persuadable voters, an advantage that could have occurred only if Obama were seen as seriously deficient in several areas, something that was extremely unlikely. A better campaign performance from McCain, combined with a weaker performance from Obama, would have resulted in a tighter election, but it is very unlikely that McCain could have achieved the advantage that he needed on character traits to win the election.

Republicans may have believed that racial prejudice would lead more white voters to evaluate Obama's character traits negatively, thus giving McCain a big advantage in this area. Our analysis did show that among white voters, those with more negative attitudes toward blacks were more likely to see McCain as superior to Obama on character traits, even controlling for other factors, such as party identification and ideology. This helps explain why McCain did very well relative to Obama on trait perceptions among white independents, even though among all voters he did worse than Obama. More generally, one analysis of the election concludes that Obama lost votes because of his race, although that study does not specifically tie that loss of votes to perceptions of character traits (Lewis-Beck and Tien 2009). However, even if McCain gained some advantage on trait perceptions due to the race of his opponent, the overall gain was far short of what he needed.

The McCain strategy did not rest solely on portraying Obama as not ready to be president. The McCain campaign also attempted to paint Obama as too liberal. They had some success in this area, especially regarding taxes (Kenski et al. 2010, 213). Perhaps a better campaign by McCain, combined with some Obama missteps, might have reduced some of McCain's popular vote deficit through more favorable perceptions of his character, relative to Obama's, and eliminated the remainder of the gap by convincing more 
voters that Obama was far too liberal. It is beyond the scope of this study to evaluate the likelihood that McCain could have gained a significantly greater advantage on issues and ideology. What we can conclude is that for McCain to have closed the popular vote gap, he would have had to accomplish more than simply shift voter perceptions of character traits in a more favorable direction.

\section{NOTES}

${ }^{1}$ There were many discussions across numerous media outlets about a potential "Bradley" or "Wilder" effect on Obama's share of the popular vote. Hopkins (2009) concluded that the gap between minority candidate poll standing and actual vote share became insignificant by the early 1990s. Moreover, while much was made of Obama's race, polls consistently showed that voters expressed more concern about McCain's age. For example, an ABC News/Washington Post poll conducted in late October showed that 90 percent of voters expressed some level of comfort with Obama becoming the first African-American president; only 50 percent said they were similarly comfortable with McCain assuming the office at 72 years of age.

${ }^{2}$ Lehman Brothers filed for Chapter 11 bankruptcy protection on September 15, 2008. This is the date many pundits consider the death knell for the McCain campaign. However, in the seven ABC News/Washington Post polls conducted from January 2008 to September 14, respondents unfailingly considered the economy the most important issue facing the country, by 9 points over the Iraq War (29 percent to 20 percent) in January and by 27 points (37 to 10) in the September 5-7 poll. Moreover, from January on, the same polling organization showed Obama with a consistent double-digit lead over McCain on the question of which candidate respondents trusted the most on the economy. The single exception was the September 5-7 poll, which showed an Obama lead of only 5 points (47 to 42). This poll was taken in the immediate aftermath of the Republican National Convention.

${ }^{3}$ An ABC News/Washington Post poll conducted in January 2008, well before either party had settled on its nominee, found that the public trusted Democrats by double digits on handling the situation in Iraq, the economy, the federal budget deficit, and health care. Moreover, Democrats had single-digit advantages on immigration and two traditionally Republican issues, the campaign against terrorism and taxes. By November, McCain reestablished a modest advantage on terrorism, but in the $18 \mathrm{ABC}$ News/Washington Post surveys taken between the financial sector collapse and election day, terrorism was never named as the most important issue by more than 7 percent of the public. About 10 percent considered the Iraq War the most important issue during this period, but Obama and McCain were essentially tied in terms of trust on this issue.

"Examples of such ads include the McCain campaign's "Special" and "Compare" ads, as well as the RNC's "Storm" ad. These ads are available at http://www.livingroom candidate.org/commercials/2008.

${ }^{5} \mathrm{McC}$ ain's behavior at this point in the campaign led at least two polling organizations, the National Annenberg Election Survey and NBC News/Wall Street Journal, to ask respondents the extent to which the term "erratic" described the Republican candidate. 
${ }^{6}$ While the Obama campaign strategy was entirely conventional, its method of presenting McCain and Bush as two sides of the same coin was often clever. One Obama 30-second ad, titled "Embrace," presented a quick succession of clips showing McCain hugging, hugging again, being kissed on the forehead by, standing with, shaking hands with, and waving to a crowd with President Bush. A second ad, "Rearview Mirror," criticized various McCain tax proposals, displayed on street signs, while a smiling President Bush looms in a car's rear and sideview mirrors. These ads can be viewed at http://www.livingroomcandidate.org/commercials/2008.

${ }^{7}$ In an early July 1960 poll, Gallup measured Eisenhower's public support at 57 percent approve, 26 percent disapprove. This was the last Gallup poll before Kennedy's mid-July speech to the Democratic National Convention, during which he laid out his vision of the New Frontier.

${ }^{8}$ Abramowitz's (2008) "Time-for-Change" model demonstrates that an incumbent party that has held the White House for at least eight years faces a penalty of about 4 percent of the popular vote, controlling for GDP and presidential approval. Thus, McCain was penalized simply for being a Republican after eight years of a Republican administration.

${ }^{9}$ Disagreement within the character trait literature is usually at the margins of the four categories noted above. Funk (1999) starts with leadership, competence, integrity, and empathy, but finds that leadership and competence are more profitably treated as forming the same dimension. Greene (2001) argues for two dimensions, competence and integrity. However in his conceptualization, competence includes leadership and integrity includes empathy. Markus (1982) also defines two trait dimensions, competence and integrity; while leadership is categorized within the competence dimension, empathy is left out entirely. Similarly, Conover (1981) argues that leadership, competence, and integrity sufficiently describe candidate character.

${ }^{10}$ The exception to this pattern are the responses about candidate honesty in 2000 and 2004. The trait question related to honesty in these years was whether the term "dishonest" described the candidates. These cell entries represent the percentage of respondents who answered "not too well" or "not well at all" when asked to consider the term "dishonest" in relation to the candidates.

${ }^{11}$ Hayes (2005) argues that Republicans tend to be advantaged on morality because of their close association with issues related to traditional values. However, we find that Democratic candidates not named Bill Clinton have faired just as well as their Republican opponents on this trait and the other integrity item, honesty.

${ }^{12}$ The Clinton campaign ad "Children," which stressed the importance of a proven leader answering the phone at 3:00 a.m. to deal with the world's problems while the country slept, made this case most dramatically during the run-up to the Texas and Ohio primaries. The ad can be viewed at http://cnettv.cnet.com/clinton-ad-children/ 9742-1 53-50023566.html.

${ }^{13}$ McCain's "Celeb" ad, which questions Obama's readiness to lead among a quick succession of attacks, can be found at http://www.livingroomcandidate.org/ commercials/2008.

${ }^{14}$ The trait items were asked in two different versions, the one that had been used in previous years and a newer version. For the older version, which uses a four-category response set, we coded extremely well as +2 , quite well as +1 , not too well as -1 , and not at all as -2 . This scoring method creates a greater distance between "quite well" and "not too well" than between the first two or the last two response categories. The difference between saying that a trait characterizes an individual "extremely well" versus "quite well" seems theoretically small. Many people might use the two terms almost inter- 
changeably. Furthermore, while "not very well" is not as negative as "not at all," the two terms seem close to each other, and both seem far from "quite well" or "extremely well." On the other hand, the distance between "quite well" and "not too well" seems substantial. For this reason, we adopted the scoring method described above. For the newer version of the trait questions, which uses a five-category response set, we coded extremely well as +2 , very well as +1 , moderately well as 0 , slightly well as -1 , and not well at all as -2 . The seven trait items are strongly correlated; the average inter-item $\mathrm{r}$ equals .66 . Cronbach's alpha for the trait index equals .93.

${ }^{15}$ Party identification was measured on the traditional seven-point scale, from strong Democrat to strong Republican. Ideology also was measured on a seven-point scale ranging from very liberal to very conservative. A substantial number of voters did not place themselves on the seven-point ideology scale but did classify themselves as liberal, moderate, or conservative with further prompting; these voters were classified as slightly liberal, moderate, and slightly conservative, respectively.

${ }^{16}$ The three questions used to form the index were: (a) How well President Bush had handled the economy; (b) Whether the national economy had gotten better or worse over the last year; and (c) Whether unemployment had gotten better or worse over the last year. The three items were all fairly strongly related, with an average inter-item gamma equal to .54. The index is the mean score on these items.

${ }^{17}$ The six questions that were used to form this index asked respondents about: (a) their opinion of Bush's handling of the war in Iraq; (b) whether they approved of the war in Afghanistan; (c) whether they approved of the war in Iraq; (d) whether the Iraq war was worth the effort; (e) whether they favored a deadline for removing troops from Iraq; and (f) whether the Iraq war made the U.S. safer from terrorism. All items were measured on a 1-3 scale. The six items were strongly related, with an average inter-item gamma equal to .69. The index is the mean score on these component items. This index captures both policy orientations and appraisals of government performance, but for the purposes of this analysis, it is not necessary to disentangle these components.

${ }^{18}$ The index of attitudes on social welfare issues was formed from three components: (a) a set of questions about spending on a variety of domestic social programs; (b) a general question about whether there should be more or less government spending and social welfare programs; and (c) a general question about the desirable level of government involvement in health care. Each component counted equally in the construction of the index. For the spending items, we formed an index by taking the mean score on five questions about whether government spending should be increased or decreased in a particular area (e.g., for aid to the poor); each question was asked in the same way for all respondents. The questions about government social welfare programs and about health care were asked in two different versions. One-half of the sample received the traditional version of these questions; the other half received a new version. Because of this, we first formed two indices: one used the spending index and the traditional versions of the other two components; the other used the spending index and the new versions of the other two components. We combined these into one index when we found that the means and standard deviations of the two separate indices were very similar. The three components are fairly strongly related; the correlations among the components average .40 for both half-samples.

${ }^{19}$ An index of moral issues was formed from: (a) a set of four items asking about gay rights; and (b) a question or set of questions on abortion. The index gave equal weight to both components. Gay rights were measured by an index that took the respondent's mean score on questions dealing with gay marriage, job discrimination, military service, and adoption rights (each measured on a 1-4 scale). These four items were all 
fairly well related, with inter-item gammas equal to .63. Abortion attitudes were measured in two different ways. One-half of the sample was given the traditional ANES item on abortion, which is a four-point scale running from never allowing abortion to always allowing it. The other half of the sample was given a set of items asking about whether abortion should be allowed in certain situations, such as if the pregnancy resulted from rape, and we calculated the mean score on these items and converted it to a 1-4 scale. Because abortion attitudes were measured in two different ways, we initially created two indices of moral issues, and we then combined them into one index when we found that the means and standard deviations of the two indices were similar. The index of gay rights correlates equally well with both measures of abortion ( $r=.49$ in both cases).

${ }^{20}$ This index was formed from: (a) an overall measure of support for blacks, built from four underlying items; (b) a question measuring the extent to which government should aid black citizens; (c) a question measuring whether government should ensure fair jobs for blacks; and (d) a measure of support for the preferential hiring and promotion of blacks. The inter-item gammas for these questions average .53. The index is the mean score on the items.

${ }^{21}$ Average Democrats are defined as those holding mean scores on the other variables. The average Democrat was a moderately liberal, weak Democrat, with a score of about 4.7 on the index of economic conditions (a 1-5 scale, where 5 is the most negative view of economic conditions), 2.6 on the national security index (a 1-3 scale, where 3 is the most liberal position), 3.1 on the social welfare issues index (a 1-7 scale, where 1 is the most liberal position), 1.8 on the moral issues index (a 1-3 scale, where 1 is the most liberal position), and 1.9 on the index of attitudes toward blacks (a 1-3 scale, where 3 is the most positive attitude toward blacks). Average independents and Republicans are similarly defined.

${ }^{22}$ In a logistic regression, the predicted probability is defined as $1 /\left(1+\mathrm{e}^{-\mathrm{Z}}\right)$, where $\mathrm{Z}$ is the predicted score from the regression equation. For a predicted probability of .50 , $\mathrm{e}^{-\mathrm{Z}}=1$; for a predicted probability of $.29, \mathrm{e}^{-\mathrm{Z}}=2.45$. Using the coefficients from our logistic regression equation (model 3 ), we can calculate the change in the trait index that would shift $\mathrm{e}^{-\mathrm{Z}}$ from 2.45 to 1 .

${ }^{23}$ Independent voters include leaners. The number of pure independents is too small to reliably analyze. The trait item on optimism was not asked in previous years, so we have no basis for comparison and therefore have not included it.

\section{REFERENCES}

Abramowitz, Alan I. 2008. Forecasting the 2008 Presidential Election with the Time-ForChange Model. PS: Political Science \& Politics 41(4):691-695.

Campbell, James E. 2008. Forecasting the 2008 Elections. PS: Political Science \& Politics 41(4):679-682.

Ceaser, James W., Andrew E. Busch, and John J. Pitney, Jr. 2009. Epic Journey: The 2008 Elections and American Politics. Lanham, MD: Rowman \& Littlefield Publishers, Inc.

Conover, Pamela J. 1981. Political Cues and the Perception of Candidates. American Politics Quarterly 9(4):427-448.

Draper, Robert. 2008. The Making (and Remaking and Remaking) of the Candidate. The New York Times Magazine, October 26, p. 54. 
Funk, Carolyn L. 1999. Bringing the Candidate into Models of Candidate Evaluation. Journal of Politics 61(3):700-720.

Goren, Paul. 2002. Character Weakness, Partisan Bias, and Presidential Evaluation. American Journal of Political Science 46(3):627-641.

Greene, Steven. 2001. The Role of Character Assessments in Presidential Approval. American Politics Research 29(2):196-210.

Greenstein, Fred I. 2009. The Presidential Difference: Leadership Style from FDR to Barack Obama, 3rd ed. Princeton: Princeton University Press.

Hayes, Danny. 2005. Candidate Qualities through a Partisan Lens: A Theory of Trait Ownership. American Journal of Political Science 49(4):908-923.

Hershey, Marjorie Randon. 2010. The Media: Coloring the News. In The Elections of 2008, ed. Michael Nelson. Washington, DC: CQ Press.

Holian, David B. 2006. Trust the Party Line: Issue Ownership and Presidential Approval from Reagan to Clinton. American Politics Research 34(6):777-802.

Hopkins, Daniel J. 2009. No More Wilder Effect, Never a Whitman Effect: When and Why Polls Mislead about Black and Female Candidates. Journal of Politics 71(3): 769-781.

Kenski, Kate, Bruce W. Hardy, and Kathleen Hall Jamieson. 2010. The Obama Victory: How Media, Money, and Message Shaped the 2008 Election. Oxford University Press.

Kinder, Donald R. 1986. Presidential Character Revisited. In Political Cognition, eds. Richard R. Lau and David O. Sears. Hillsdale, NJ: Lawrence Erlbaum.

Lewis-Beck, Michael S., and Charles Tien. 2009. Race Blunts the Economic Effect? The 2008 Obama Forecast. PS: Political Science \& Politics 42(1):21.

Markus, Gregory B. 1982. Political Attitudes during an Election Year. American Political Science Review 76(3):538-560.

McCann, James A. 1990. Changing Electoral Contexts and Changing Candidate Images During the 1984 Presidential Campaign. American Politics Quarterly 18(2):123140.

Miller, Warren E., and J. Merrill Shanks. 1996. The New American Voter. Cambridge, MA: Harvard University Press.

Petrocik, John R. 1996. Issue Ownership in Presidential Elections, with a 1980 Case Study. American Journal of Political Science 40(3):825-850.

Pierce, Patrick A. 1993. Political Sophistication and the Use of Candidate Traits in Candidate Evaluation. Political Psychology 14(1):21-35.

Vavreck, Lynn. 2009. The Message Matters: The Economy and Presidential Campaigns. Princeton: Princeton University Press. 